\title{
The Ystad Project - A Case Study for Multidisciplinary Research on Long-Term Human Impact
}

"The cultural landscape during 6000 years in southern Sweden" was the topic for a multidisciplinary study of an area bordering the town of Ystad in southermost Sweden during the 1980's. The study area (30 000 ha), covering a coastal lowland and an inland upland involved a gradient from a "central" and early inhabited area to a "marginal" and late inhabited area. Such an ecological gradient is typical for many regions in Europe and this is also convenient for settlement and landscape historical studies, since it is then easier to detect signals of so-called expansions and regressions of settlement and agrarian activities. The main aim of the project was the documentation of such a pattern, which was earlier described by pollen analysts (Berglund 1969), but not compared with archeological data in a systematic way. Our project employed a coordinated strategy for paleoecologists, archeologists, historians, human geographers and plant ecologists in order to describe the landscape history from the introduction of agriculture until modern time, the interaction between humans and environment and the causes behind Late Holocene landscape changes. Inventories were made in the entire area, key sites (often lake catchments) were selected along the main gradient for paleoecological and settlement historical field studies. The paleoecological techniques involved were pollen and plant macrofossil analyses, diatom analysis, sediment geochemical and mineralmagnetic analyses. Combined paleoecological and archeological data made it possible to interpret the land use patterns and the openness of the landscape for ten selected time windows. These data resulted in ten landscape historical maps for the entire area, and some more detailed maps for selected village areas. The calibration procedure for paleodata was semiobjective; quantification methods are still under development (Sugita et al. 1999). A survey diagram demonstrates the general pattern of the cultural landscape development, comparing coast/inland and dry/wet ground (Fig. 1). This project resulted in one main interdisciplinary, monographic synthesis (Berglund 1991), two archeo-

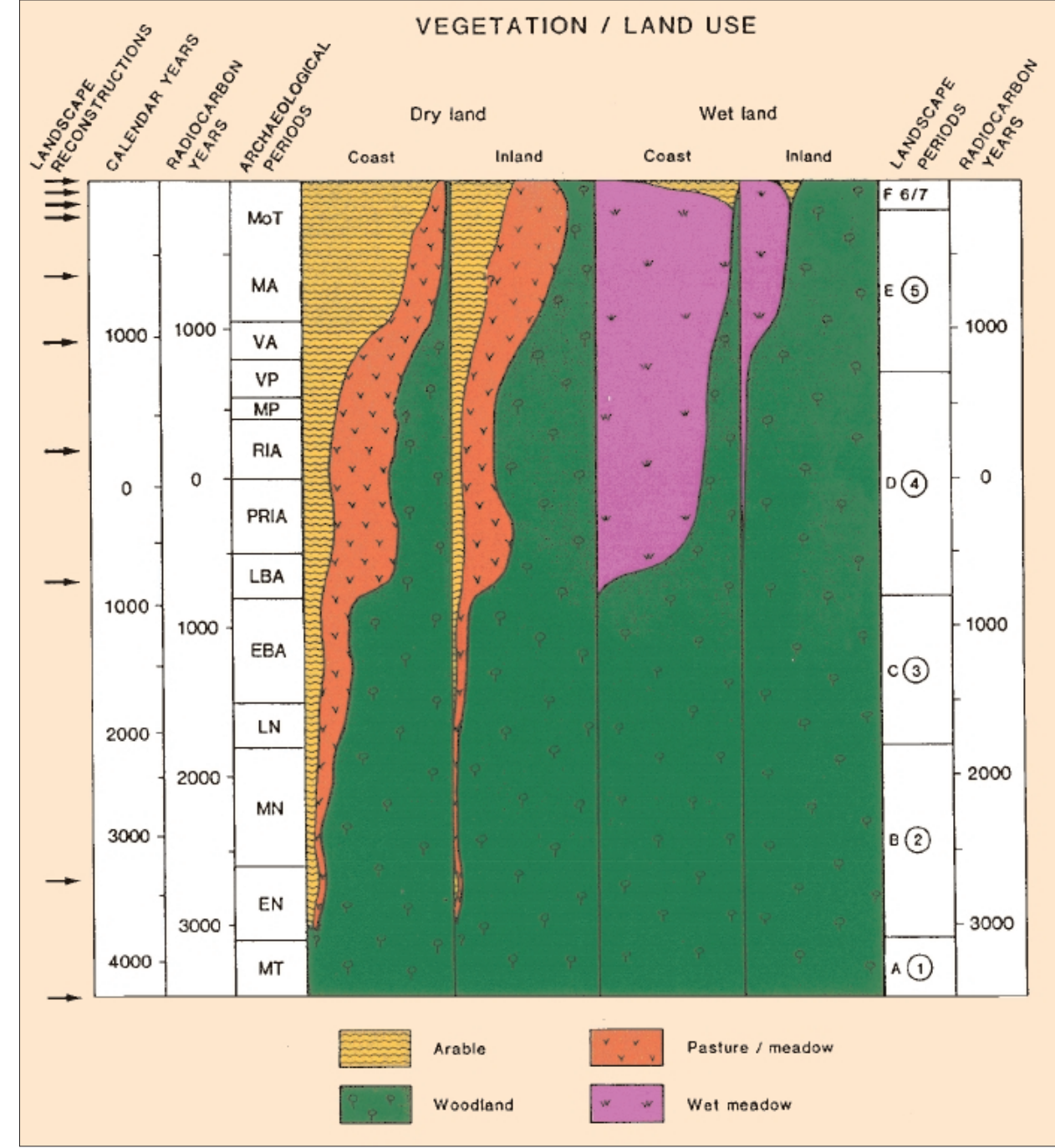

Figure 1: Synthesis diagram based on 10 pollen diagrams from the Ystad area, Southern Sweden, showing the deforestation and land-use pattern for the last 6000 years (Berglund 1991). Landscape reconstructions (maps) have been performed for the 10 time windows indicated by arrows.

logical monographs and numerous journal papers.

The results from southern Sweden may be correlated with similar studies in a wider geographical area. Within Southern Scandinavia (Denmark and Southern Sweden) we can identify five obvious expansion periods during the last 6000 years. They correspond to the beginnings of the landscape periods 2 to 6 indicated in Fig. 1. A further correlation has been done by using numerous pollen diagrams along a NW European transect from Ireland to Estonia (Berglund et al. 1996), in fact showing great synchroneity of two main phases of human expansion, which lead to deforestation and some erosion in NW Europe: c. 1000-800 BC and AD 600-1000 (Fig. 2).
In the synthesis of the Ystad project the causes behind the landscape/land use changes were discussed. The background to the expansion phases were generally found in the changes of the society in Central Europe (population pressure, organization, economy, technology, etc), impacting on Southern Scandinavia. However, when compiling and comparing the most important human impact events of the agrarian society in NW Europe, expansions as well as regressions, it is striking that environmental changes caused by climate change occurred at the same time (Fig. 3). The timing even shows a pattern similar to the Bond cycles, with coolings at c. 5900, 4200, 2800 and $1400 \mathrm{BP}$ (Bond et al. 1997). However, to quantify such correlations requres improved dating 


\section{Deforestation pattern in NW Europe}

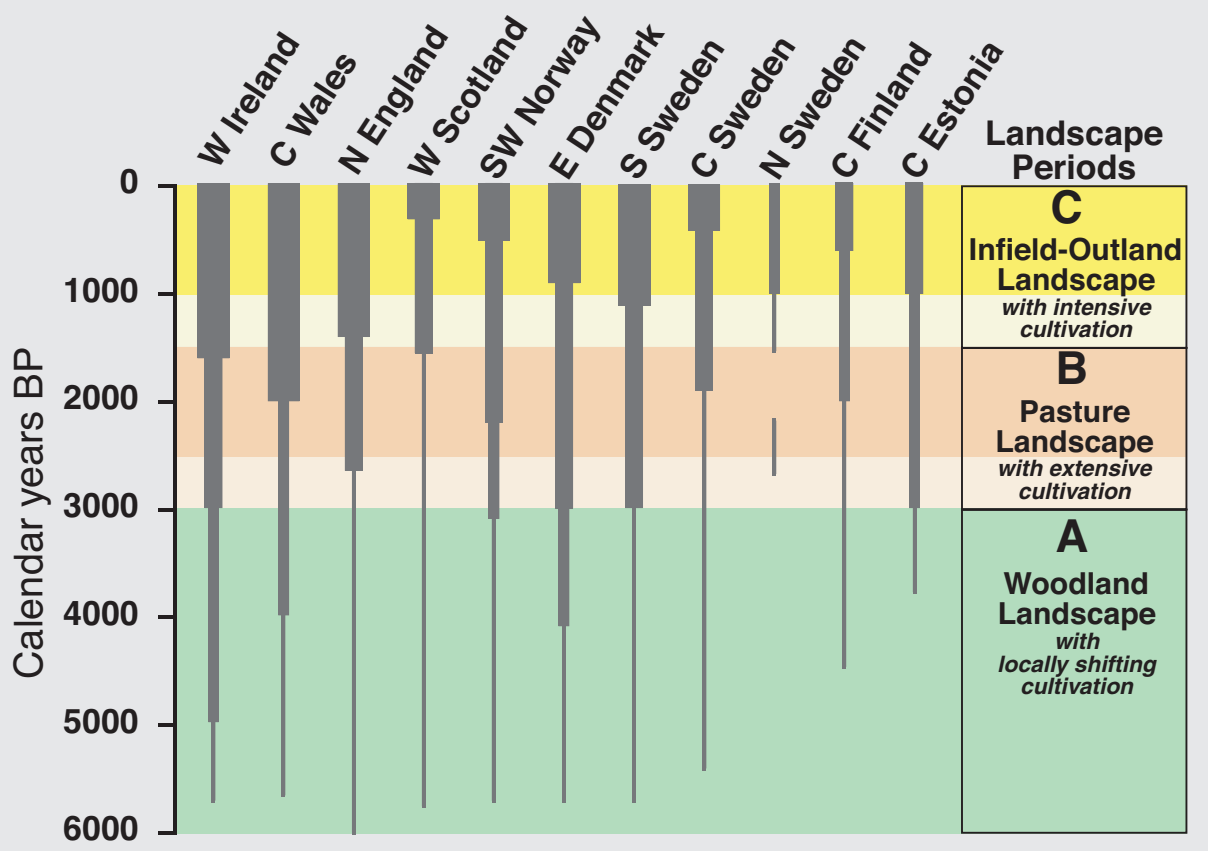

Figure 2: Deforestation pattern in NW Europe, which indicates the main changes of land-use and cultural landscape after 1000 BC and before AD 1000 (based on Berglund et al. 1996).

\begin{tabular}{|c|c|c|c|c|}
\hline \multicolumn{5}{|c|}{ Human impact /climate change events in NW Europe } \\
\hline Event & Age cal BP & Human impact & Climate change & Geogr. area \\
\hline 1 & $5900 \mathrm{BP}$ & $\begin{array}{l}+ \text { agriculture: } \\
\text { deforestation } \\
\text { erosion? }\end{array}$ & $\begin{array}{l}+ \text { tree limit } \\
-\quad \text { glaciers } \\
-\quad \text { lake level }\end{array}$ & NW Europe \\
\hline 2 & $5500 \mathrm{BP}$ & 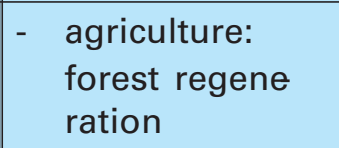 & $\begin{array}{ll}- & \text { tree limit } \\
+ & \text { lake level }\end{array}$ & NW Europe \\
\hline 3 & $4500 \mathrm{BP}$ & \begin{tabular}{|l} 
+ \\
agriculture: \\
deforestation \\
heathexpansion
\end{tabular} & $\begin{array}{l}+ \text { bogs } \\
+ \text { glaciers }\end{array}$ & $\begin{array}{l}\text { Ireland } \\
\text { Scandinavia }\end{array}$ \\
\hline 4 & $3800 \mathrm{BP}$ & $\begin{array}{l}\text { agriculture: } \\
\text { deforestation }\end{array}$ & $\begin{array}{ll}- & \text { tree limit } \\
+ & \text { bogs } \\
+ & \text { erosion }\end{array}$ & $\begin{array}{l}\text { Scotland } \\
\text { Scandinavia }\end{array}$ \\
\hline 5 & $\begin{array}{l}3000- \\
2800 \mathrm{BP}\end{array}$ & $\begin{array}{l}\text { + agriculture: } \\
\text { deforestation } \\
\text { erosion }\end{array}$ & $\begin{array}{l}\text { - } \text { tree limit } \\
+ \text { glaciers } \\
+ \text { bogs } \\
+ \text { lake level }\end{array}$ & $\begin{array}{l}\text { Ireland } \\
\text { S Scandinavia } \\
\text { Poland } \\
\text { Holland }\end{array}$ \\
\hline 6 & $1500 \mathrm{BP}$ & - agriculture: & $\begin{array}{ll}\text { - } & \text { pine growth } \\
+ & \text { bogs }\end{array}$ & NW Europe \\
\hline 7 & $1100 \mathrm{BP}$ & $\begin{array}{l}+ \text { agriculture: } \\
\text { deforestation } \\
\text { erosion }\end{array}$ & $\begin{array}{l}+ \text { tree limit and } \\
\text { pine growth } \\
-\quad \text { glaciers } \\
-\quad \text { bogs }\end{array}$ & $\begin{array}{l}\text { NW Europe } \\
\text { C Europe }\end{array}$ \\
\hline
\end{tabular}

precision and a better understanding of the climate signals (cf. Sandweiss et al. 1999). Some of these events seem to involve complex climate dynamics of cool as well as warm phases, e. g. events 1 and 5 .

Future research on long-term human impact, in Europe as well as worldwide, should preferably adopt the following strategy:

- apply multidisciplinary paleoecological research in a network of key areas

- combine paleoecology and archeology in order to obtain mutual calibration of data

- use high-resolution chronology, i.e. annually laminated sediments or wiggle matching radiocarbon dates (cf. Ralska-Jasiewiczowa et al. 1998, Segerström 1999, Snowball et al . 1999, Zolitschka 1998)

- calibrate paleovegetation data by using the modern analogue technique (cf. Sugita et al. 1999)

- develop methods and strategies for discriminating climate change from human impact

\section{B.E. BergLUND}

Department of Quaternary Geology, University of Lund, Sweden

Biorn.Berglund@geol.lu.se

\section{Main Reference}

Berglund, B. E. (ed.) 1991, Ecological Bulletins 41.

For full references please consult www.pagesigbp.org/products/newsletters/ref2003.html

Figure 3: Comparison of human impact and climate change in NW Europe for selected events (1-7). The direction of the ecological change patterns are described with + for expansion/rise, with - for regression/reduction/lowering. Selected references (besides Berglund 1991,1996): event 1 (Digerfeldt 1988, Karlén and Kuylenstierna 1996, Karlén and Larsson 1999, Sandweiss et al. 1999), event 2 (in addition to event 1: Molloy and O 'Connell 1995, Schibler et al. 1997), event 3 (Aaby 1976, Karlén and Kuylenstierna 1996, Molloy and O`Connell 1995), event 4 (Aaby 1976, Anderson et al. 1998, Karlén and Kuylenstierna 1996, Snowball et al. 1999, 2000), event 5 (Aaby 1976, Digerfeldt 1988, Karlén and Kuylenstierna 1996, Kullman 1988, Snowball et al. 1999, 2000), van Geel et al. 1996), event 6 (Aaby 1976, Eronen et al. 1999, Karlén and Kuylenstierna 1996), event 7 (as event 6). 